\title{
DESAIN SISTEM KONTROL LAJU ALIRAN MASSA SPRAYER MENGGUNAKAN PULSE WIDTH MODULATION
}

\author{
MUHAMMAD ADAM ALFATH DAN BAMBANG JOKO SUROTO* \\ Departemen Fisika, \\ Fakultas Matematika dan Ilmu Pengetahuan Alam, Universitas Padjadjaran \\ Jl. Raya Bandung-Sumedang Km 21, Jatinangor 45363 \\ *email : bambang.s@phys.unpad.ac.id
}

\begin{abstract}
Abstrak. Telah dibuat sistem kontroler laju aliran massa dari sprayer menggunakan metode pulse width modulation. PWM digunakan sebagai sinyal kontrol solenoid valve dimana didapatkan hasil bahwa pengaturan nilai frekuensi dan duty cycle untuk aktuator dapat mengendalikan keluaran aliran massa sprayer secara presisi. Dalam percobaan didapatkan bahwa perubahan duty cycle untuk frekuensi tetap berbanding lurus terhadap laju aliran massa output sprayer dengan koefisien determinasi $\mathbf{R}^{2}=1,00$.
\end{abstract}

Kata kunci : spray, sistem kontrol, pulse width modulation, laju aliran massa

Abstract. A sprayer mass flow control system has been made using pulse width modulation method. PWM is used as control signal for solenoid valve where the setting value of frequency and duty cycle for actuator can control the sprayer mass flow output precisely. In experiment observed that the change of duty cycle for fixed frequency is proportional to the sprayer mass flow rate output with the coefficient of determination $\mathrm{R}^{2}=1,00$.

Keywords : spray, control system, pulse width modulation, mass flow rate

\section{Pendahuluan}

Pemenuhan spesifikasi akan spraying ataupun coating dengan presisi tinggi sangat dibutuhkan dalam sistem kontrol, yang mana berpengaruh pada kualitas hasil (jumlah fluida output, kemerataan di permukaan) dan juga ongkos produksi (pemakaian fluida) [1,2]. Salah satu parameter yang ditinjau dalam pembuatan kontrol spray presisi adalah laju aliran (flow rate). Metode tradisional yang digunakan untuk mengatur laju aliran fluida adalah dengan mengatur tekanan dari spray. Namun metode ini sudah tidak efisien dan tidak lagi memenuhi standar kualitas dikarenakan terbatas pada kapasitas laju aliran dari nozzle yang terpasang di sprayer [1]. Dengan kemunculan mikroprosesor dan teknologi switching, pulse width modulation (PWM) telah digunakan untuk kebutuhan kontrol presisi [3]. PWM dapat digunakan untuk mengkontrol laju aliran fluida dengan mengubah nilai duty cycle pada frekuensi tetap $[4,8]$.

Durasi saat nozzle pada posisi aktif/on disebut duty cycle/lebar pulsa (pulse width). Lebar pulsa mendefinisikan rasio waktu aktif $t_{\text {on }}$ terhadap total waktu siklus $T$ dalam persen. Modulasi dari lebar pulsa mempegaruhi nilai $t_{\text {on }}$ dan $t_{\text {off }}$ secara bersamaan, dengan demikian juga menentukan nilai dari laju aliran. 


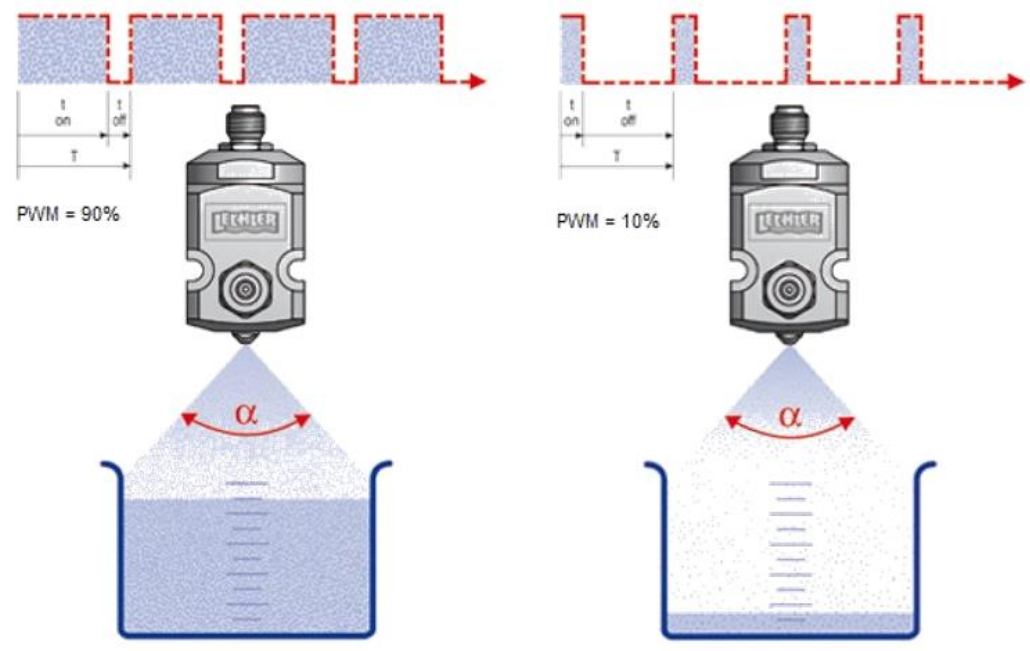

Gambar 1. Kontrol laju aliran menggunakan PWM [5]

\section{Metode Penelitian}

Sistem kontrol ini di desain sebagai modul yang sudah terintegrasi dengan antarmuka input, display, serta driver aktuator. Fluida kerja yang digunakan dalam pengujian ini berupa air suling yang nilai temperatur dan tekanannya dikontrol stabil sehingga inlet diasumsikan memiliki nilai yang konstan untuk setiap pengujian. Untuk melihat kinerja kontrol, dilakukan variasi terhadap nilai pulsa PWM dan diamati hubungannya terhadap nilai laju aliran massa yang dihasilkan.

\subsection{Perancangan Sistem}

Sistem kontroler dibangun menggunakan mikrokontroller ATmega328P yang bekerja pada clock $16 \mathrm{MHz}$ dengan antarmuka berupa LCD dan push-button yang berfungsi untuk menampilkan atau men-set nilai frekuensi dan duty cycle yang diinginkan. Aktuator yang digunakan dalam sistem ini berupa solenoid valve 2W025-08 bertipe normally closed dengan rating kerja $12 \mathrm{~V}$ dengan waktu respon minimum $t_{\text {respond }}=20 \mathrm{~ms}$ [6,7]. Untuk keperluan tersebut digunakan fitur fast switching pada power MOSFET IRF520 yang dikendalikan oleh pulsa TTL dari mikrokontroller.

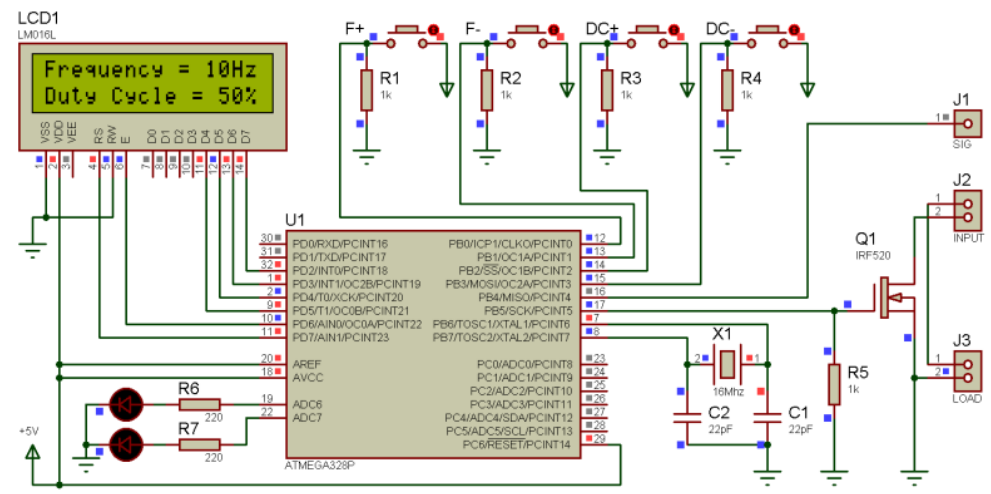

Gambar 2. Rangkaian elektronik kontroler sprayer 
Kontroler akan bekerja saat pin SIG diberi nilai eksternal HIGH dan akan berhenti jika diberi nilai LOW. Sinyal PWM akan otomatis dihasilkan berdasarkan parameter sebelumnya telah di-set oleh pengguna dengan perhitungan:

$$
\begin{aligned}
& t_{\text {on }}=\frac{1}{f} \times D C \\
& t_{\text {off }}=\frac{1}{f}-\left(\frac{1}{f} \times D C\right)
\end{aligned}
$$

dengan $t_{\text {on }}$ merupakan waktu aktif/on (s), $t_{\text {off }}$ merupakan waktu non-aktif/off (s), $f$ merupakan frekuensi pulsa $(\mathrm{Hz})$ dan $D C$ merupakan nilai duty cycle. Sistem ini dirancang untuk bekerja pada rentang frekuensi $0-10 \mathrm{~Hz}$ dengan variasi duty cycle yang memenuhi kondisi dimana $t_{\mathrm{on}}, t_{\mathrm{off}}<0,02 \mathrm{~s}$, yang mana merupakan spesifikasi waktu respon dari aktuator.

\subsection{Pengujian Kontroler Spray}

Setting sistem di rangkai seperti yang ditunjukan Gambar 3. Pengujian sistem dilakukan dengan memberikan pulsa HIGH pada pin SIG selama $t_{\mathrm{SIG}}=60 \mathrm{~s}$ dengan variasi frekuensi dan duty cycle sebagai variabel bebas serta massa fluida output sebagai variabel terikat. Parameter sistem yang digunakan pada eksperimen tercantum pada Tabel 1 .

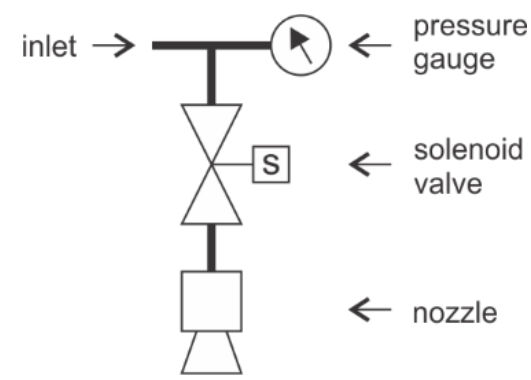

Gambar 3. Tampilan skematik sistem

Tabel 1. Nilai parameter eksperimen

\begin{tabular}{lc}
\hline \multicolumn{1}{c}{ Parameter } & Nilai \\
\hline Tekanan Inlet $\left(\mathrm{P}_{\text {inlet }}\right)$ & $800 \mathrm{kPa}$ \\
Temperatur Fluida $\left(\mathrm{T}_{\text {fluid }}\right)$ & $295,77 \mathrm{~K}$ \\
Nozzle Orifice $(\mathrm{d})$ & $0,2 \mathrm{~mm}$ \\
Koefisien Aliran $\left(\mathrm{C}_{\mathrm{v}}\right)$ & 0,23 \\
\hline
\end{tabular}

\section{Hasil dan Pembahasan}

Gambar 4. menunjukan kurva pengaruh nilai sinyal PWM terhadap laju aliran massa fluida keluaran dengan variasi frekuensi spraying $1 \mathrm{~Hz}, 5 \mathrm{~Hz}$ dan $10 \mathrm{~Hz}$. Untuk setting frekuensi tetap, variasi nilai duty cycle memiliki pengaruh linier terhadap massa fluida per satuan waktu. Kurva linier ini dibatasi oleh rentang kerja respon aktuator dimana saat $t_{\text {on }}<t_{\text {respond }}$ maka selonoid akan langsung berada dalam keadaan fully closed, serta saat $t_{\text {off }}<t_{\text {respond }}$ selonoid akan langsung berada pada keadaan fully open. 


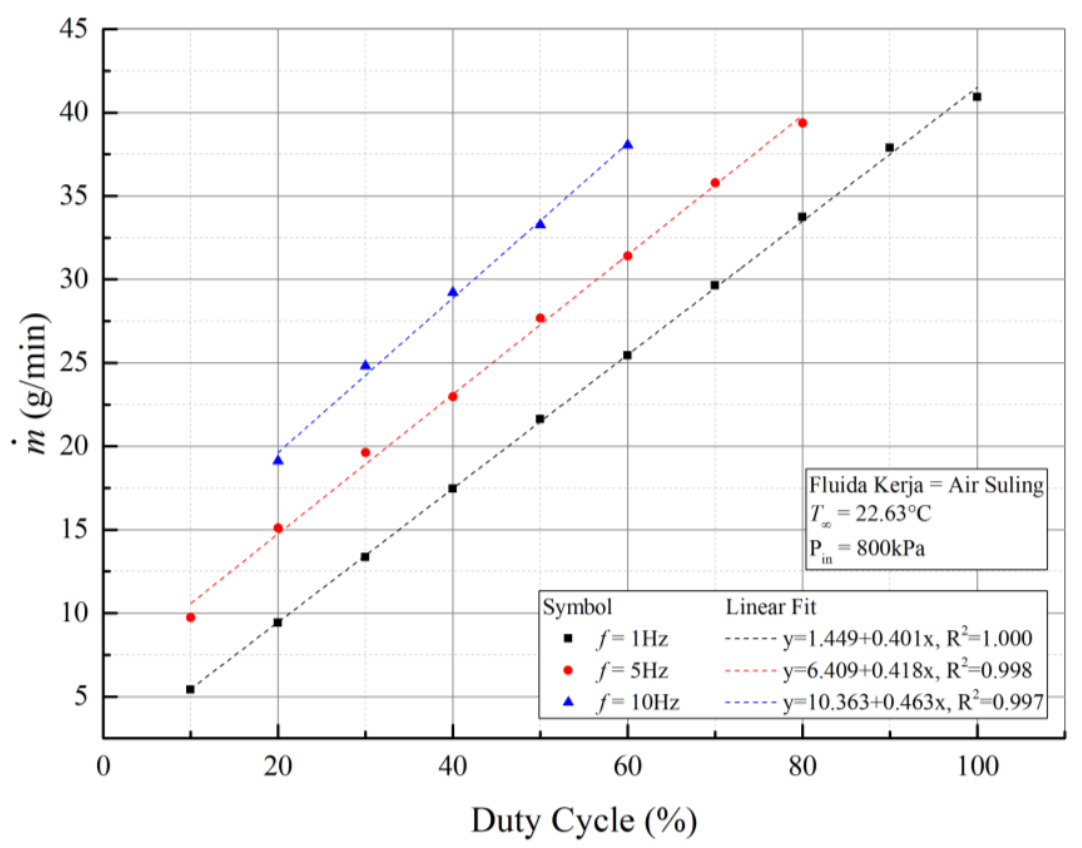

Gambar 4. Pengaruh Kontrol PWM terhadap Laju Aliran Massa

Dari tinjauan pada segi kebutuhan output, terlihat bahwa pemilihan frekuensi PWM $1 \mathrm{~Hz}$ memberikan kontrol output yang akurat dari semua rentang kapasitas aliran dengan persamaan linier:

$$
\dot{m}=1,449+(0,401 \times D C) \quad R^{2}=1,00
$$

\section{Kesimpulan}

Telah dibuat sistem kontrol spray menggunakan pulse width modulation dimana didapatkan hasil bahwa pengaturan nilai frekuensi dan duty cycle untuk aktuator dapat mengendalikan keluaran sprayer secara presisi. Dalam pengamatan parameter laju aliran massa sprayer didapatkan bahwa perubahan duty cycle untuk frekuensi tetap berbanding lurus terhadap laju aliran massa output dengan koefisien determinasi $\mathrm{R}^{2}=1,00$.

\section{Daftar Pustaka}

1. J.W. Kohley. 2009. Optimising Spray Performance with Pulse Width Modulated Flow Control. USA: Spraying Systems Co.

2. T. Wolf. 2017. Spray Application Manual for Grain Growers. Australia: Grains Research and Development Corporation.

3. H. Zhu, Y. Lan, W. Wu, W. Clint Hoffmann, Yanbo Huang, Xinyu Xue, Jian Liang, and Brad Fritz. Development of a PWM Precision Spraying Controller for Unmanned Aerial Vehicles, Journal of Bionic Engineering, 2010, Vol. 7, No. 3, 276-283.

4. G. C. Bora, M. D. Schrock, D. L. Oard, J. J. Grimm, T. C. Kolb, J. J. Higgins, Reliability Tests of Pulse Width Modulation (PWM) Valves for Flow Rate Control of Anhydrous Ammonia. Applied Engineering in Agriculture, 2005, Vol. 21, No. 6, 955-960. 
5. "Pulse-Width Modulation for Precise Flow Rate Control." Pulse Width Modulation Technology. Lechler GmbH, 9 September 2016. Web. 28 Januari 2018.

6. China SNS Pneumatic Co., Ltd., "2W Series Solenoid Valve," 2W025-08 Datasheet, 13 Desember 2006.

7. S. Suryaningsih, J. Y. Mindara, S. Hidayat, I. Chaerunnisa, Rancang Bangun Alat Ukur Kadar Gas CO Berbasis Nirkabel RF Untuk Pemantauan Kondisi Pencemaran Udara, Jurnal Ilmu dan Inovasi Fisika Vol 01. No.01 (2017), p. 45-50.

8. D. Hidayat, M. E. Simatupang, N. Suhendi, B. M. Wibawa, Pembangkit Pulsa Orde Nano/Mikro Detik untuk Pemicu Tranduser Ultrasonik, Jurnal Ilmu dan Inovasi Fisika Vol 02 No. 01 (2018), p. 30-36. 